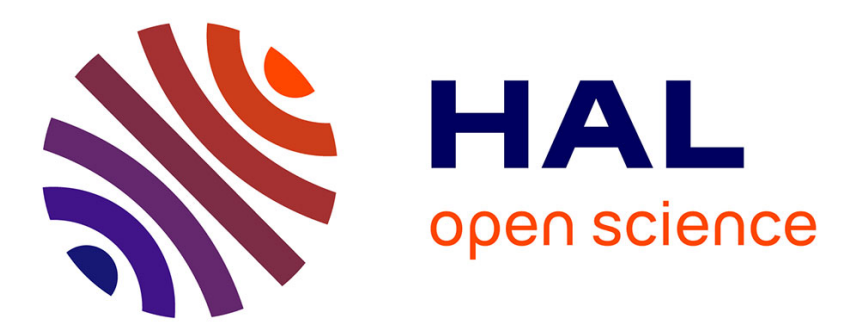

\title{
Isolation and characterization of fifteen microsatellite loci for the giant clam Hippopus hippopus (family Tridacnidae)
}

\author{
Josina Tiavouane, Théa Jacob, Pascal Dumas, Cécile Fauvelot
}

\section{To cite this version:}

Josina Tiavouane, Théa Jacob, Pascal Dumas, Cécile Fauvelot. Isolation and characterization of fifteen microsatellite loci for the giant clam Hippopus hippopus (family Tridacnidae). Conservation Genetics Resources, 2014, 6, pp.735 - 737. 10.1007/s12686-014-0203-y . ird-03044252

\section{HAL Id: ird-03044252 \\ https://hal.ird.fr/ird-03044252}

Submitted on 24 Sep 2021

HAL is a multi-disciplinary open access archive for the deposit and dissemination of scientific research documents, whether they are published or not. The documents may come from teaching and research institutions in France or abroad, or from public or private research centers.
L'archive ouverte pluridisciplinaire HAL, est destinée au dépôt et à la diffusion de documents scientifiques de niveau recherche, publiés ou non, émanant des établissements d'enseignement et de recherche français ou étrangers, des laboratoires publics ou privés. 


\title{
Isolation and characterization of fifteen microsatellite loci for the giant clam Hippopus hippopus (family Tridacnidae)
}

\author{
Josina Tiavouane ${ }^{(1)}$, Théa Jacob ${ }^{(2)}$, Pascal Paul Dumas ${ }^{(3)}$, Cécile Fauvelot ${ }^{(1)^{*}}$ \\ (1) Institut de Recherche pour le Développement (IRD), LabEx CORAIL, UR 227 CoReUs 2, BPA5, 101 \\ Promenade Roger Laroque, 98848 Noumea cedex, New Caledonia.
}

${ }^{(2)}$ World Wildlife Fund (WWF), Bureau WWF Nouvelle-Calédonie, Parc Forestier Michel Corbasson, BP692, 98845 Nouméa cedex, New Caledonia.

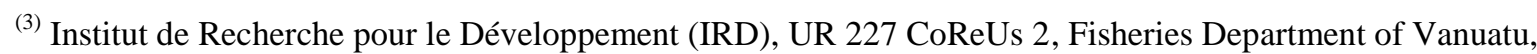
Port-Vila, Vanuatu. Tél. (678) 23 174, Fax (678) 23641.

*Corresponding author. E-mail: cecile.fauvelot@ird.fr

\begin{abstract}
Fifteen polymorphic microsatellite markers were developed for Hippopus hippopus in order to assess the effectiveness of population replenishment within MPAs in New Caledonia. Number of alleles varied from 2 to 11 per locus, observed and expected heterozygosities ranged from 0.300 to 0.866 and 0.495 to 0.858 respectively. Significant deviations from HWE were detected in two loci. Cross-amplifications were tested in four other species of Tridacnidae.
\end{abstract}

\section{Keywords}

Hippopus hippopus; Tridacnidae; microsatellite loci; Marine Protected Area; paternity analyses; New Caledonia

Giant clams are an important though declining resource for the Indo-Pacific countries. Because of the overexploitation for its meat and shell, Hippopus hippopus (Linné 1758) is already extinct from several island countries and is listed on the IUCN Red List of Threatened Species since 2004. Alerted by recent stock declines in New Caledonia, in agreement and following local communities wish, World Wildlife Fund with the support of the Department of Fisheries and Aquaculture of the Northern Province initiated and coordinated a restocking 
event of Hippopus hippopus in September 2009 within the co-managed Marine Protected Areas (MPAs) of the North-East Lagoon: Hyabé/LeJao (Pouébo) and Yeega (Hienghène). Microsatellite loci were developed to provide genetic tools for assessing the effectiveness of this replenishment and estimating spatial scales of larvae dispersal of this species from these MPAs.

Approximately $20 \mathrm{ng}$ of genomic DNA was isolated from muscle tissue of one individual conserved in 80\% EtOH. Size-selected fragments from genomic DNA were enriched for SSR content by using magnetic streptavidin beads and biotin-labeled CT and GT repeat oligonucleotides. The SSR-enriched library was analyzed on a Roche 454 platform using the GS FLX Titanium reagents. From the 28'526 reads, 1'689 contained a microsatellite insert with a tetra- or a trinucleotide of at least 6 repeat units or a dinucleotide of at least 10 repeat units. Suitable primer design was possible in 4141 reads and 72 were tested for polymorphism on 8 individuals. Genomic DNA was isolated from mantel biopsies using DNeasy Blood and Tissue Kit (Qiagen). PCR reactions were performed using Type-It Microsatellite (Qiagen) in two distinct multiplexes of $5 \mu 1$ final volume containing $1 \mathrm{X}$ Master Mix, $0.5 \mathrm{X}$ of Q-solution, $0.1 \mu \mathrm{M}$ of each primer (fluorescent-labeled forward primer 6-FAM, PET, NED or VIC) and 50 to 150ng of DNA template (Table 1). PCRs were conducted in GeneAMP PCR System 9700 (Applied Biosystems) with $5 \mathrm{~min}$ at $94^{\circ} \mathrm{C}, 28$ cycles at $95^{\circ} \mathrm{C}$ for $30 \mathrm{~s}, 57^{\circ} \mathrm{C}$ for $90 \mathrm{~s}$ and $72^{\circ} \mathrm{C}$ for $30 \mathrm{~s}$, and a final step at $60^{\circ} \mathrm{C}$ for $30 \mathrm{~min}$. Fluorescent PCR fragments were visualized on an ABI 3130XL Genetic Analyser (Applied Biosystems) with GS-500-LIZ (Applied Biosystems). Alleles were sized using the program GeneMapper® (Applied Biosystems).

Using GENETIX (Belkhir et al. 2002), between 2 and 11 alleles (mean $=7.54$ ) were observed per locus among 30 individuals from Hyabé/LéJao (Pouébo) MPA, with expected heterozygosity values ranging from 0.495 to 0.858 (Table 1). No significant genotypic linkage disequilibrium among loci was found using GENEPOP (Raymond and Rousset 1995). Significant deviations from Hardy-Weinberg equilibrium were observed at Hiphip_13326 and Hiphip_14220 after Bonferroni corrections. Null alleles were suggested at these two loci by MICRO-CHECKER (Van Oosterhout et al. 2004) and confirmed by the presence of null homozygotes.

Cross-priming was tested on 8 individuals of Tridacna crocea (from New Caledonia), T. maxima (from La Réunion, Juan de Nova and Glorieuses, Indian Ocean), T. squamosa (from Juan de Nova and Glorieuses) and T. derasa (from New Caledonia). Using the same PCR conditions as above, but an annealing temperature of $52^{\circ} \mathrm{C}$, the test resulted in 12 loci amplifying in $T$. crocea; 5 loci amplifying in T. maxima; 2 loci amplifying in $T$. squamosa; and 8 loci amplifying in T.derasa (Table 2).

The 15 new microsatellite loci will be helpful tools for connectivity studies on H. hippopus populations and to investigate genetic stocks for fisheries management of this endangered species.

\section{Acknowledgements}

This work was funded by World Wildlife Fund France, within the framework of the project entitled "Connectivity of Hippopus hippopus populations in the North-Eastern lagoon of New Caledonia" with the support of Northern Province of New Caledonia. Thanks to Pouébo and Hienghène associations of co-managed 
MPAs, local communities, and fishermen for their help on the field, support and interest in this project. This work is part of the PhD of JT, granted by North and South Provinces of New Caledonia.

\section{References}

Belkhir K, Borsa P, Chikhi L, Raufaste N, Bonhomme F (2002) GENETIX 4.02, Logiciel sous Windows TM pour la génétique des populations. Laboratoire Génome, Populations, Interactions, CNRS-UMR 5000, Université de Montpellier II, Montpellier

Raymond M, Rousset F (1995) GENEPOP (version 1.2): population genetics software for exact tests and ecumenicism. J Heredity 86:248-249. Genepop on the web, (http://genepop.curtin.edu.au/index.html): Accessed 18 February 2014

Van Oosterhout C, Hutchinson WF, Wills DPM, Shipley P (2004) Micro-Checker: Software for Identifying and Correcting Genotyping Errors in Microsatellite Data. Mol Ecol Notes 4:535-538 